\section{Dinucleotide repeat polymorphism at the $3^{\prime}$ end of the LDL receptor gene}

Giovanni Zuliani and Helen H.Hobbs

Department of Molecular Genetics, University of Texas Southwestern Medical Center, 5323 Harry Hines Boulevard, Dallas, TX 75235, USA

Source/Description: A polymorphic dinucleotide tandem repeat (dTùdA) is located in exon 18 of the LDL receptor gene (at nucleotide 4780) (1). Two oligonucleotides homologous to the sequences flanking the tandem repeat (GZ-7 and GZ-8) were used to amplify the region and generate a fragment of the predicted size. of $106 \mathrm{bp}$.

Primer Sequences:

GZ-7 = CACTTTGTATATTGGTTGAAACTGT

GZ-8 = CACTGAACAAATACAGCAACCAGGG

Frequency: Estimated in 27 unrelated Caucasian American individuals:

$\begin{array}{lll}\text { Allele (nt) } & \begin{array}{l}\text { Number of } \\ \text { (TA) Repeats }\end{array} & \text { Frequency } \\ 112 & 10 & 0.20 \\ 108 & 8 & 0.10 \\ 106 & 7 & 0.70\end{array}$

The heterozygosity index was $48.5 \%$.

Mendelian Inheritance: Co-dominant segregation was observed in two families with a total of seven informative meiosis.

Chromosomal Localization: The LDL receptor gene has been assigned to chromosome 19p13.1-p13.3. (2).

Other Comments: The PCR reaction was performed on genomic DNA as previously described (3) with the following modifications: 1) the DNA was denatured at $96^{\circ} \mathrm{C}$ for $1 \mathrm{~min}$, 2) annealing and extension was performed at $68^{\circ} \mathrm{C}$ for $3 \mathrm{~min}$, and 3 ) the number of cycles was 20. PCR products were fractionated on an $8 \%$ denaturing polyacrylamide gel and the size of the alleles was determined by comparison with end-labeled MspI digested pBR322 DNA. The analysis of a Puerto Rican family with familial hypercholesterolemia showed an additional allele of $114 \mathrm{nt}$ (11 repeats) not seen in any Caucasian American individuals.

References: 1) Yamamoto,T. et al. (1984) Cell 39, 27-38. 2)Lindgren,N.V. et al. (1985) Proc. Natl. Acad. Sci. USA 82 , 8567-8571. 3) Saiki,R.K. et al. (1988) Science 230, 487-491.

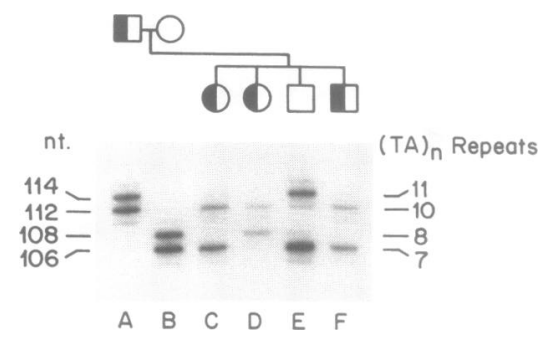

Pvull and Xhol/EcoRV polymorphisms adjacent to the $\alpha$ A-crystallin (CRYA1) gene on human chromosome 21

Michael B.Petersen, Cynthia J.Jaworski ${ }^{1}$, John G.Lewis and Stylianos E.Antonarakis

Department of Pediatrics (Genetics Unit), The Johns Hopkins University School of Medicine, Baltimore, MD 21205 and ${ }^{1}$ Laboratory of Molecular and Developmental Biology, National Eye Institute, National Institutes of Health, Bethesda, MD 20892, USA

Source/Description: An 1800 bp KpnI/HindIII single copy genomic DNA insert in bacteriophage M13 mp19 was used as a hybridization probe. This clone ( $\alpha A-\mathrm{A} 2)$ contains a fragment of the human $\alpha$ A-crystallin gene, that includes exons 1 and 2 and a portion of intron 2 (1).

Polymorphisms: After PvuII digestion the p $\alpha \mathrm{A}-\mathrm{T} 2$ probe reveals a VNTR polymorphism with at least 4 alleles between $7.8 \mathrm{~kb}$ and $10.5 \mathrm{~kb}$. A constant fragment of $1.5 \mathrm{~kb}$ is also observed. A double digest with XhoI/EcoRV reveals a second DNA polymorphic system with allelic fragments of A1: 5.2 and 14.0 $\mathrm{kb}, \mathrm{A} 2: 16.5$ and $21.0 \mathrm{~kb}$ and A3: $17.0 \mathrm{~kb}$.

Frequency: The observed heterozygosity of the PvuII VNTR polymorphism in the $40 \mathrm{CEPH}$ families is $34 \%$. The frequency of the alleles of the Xhol/EcoRV polymorphism in $183 \mathrm{CEPH}$ chromosomes studied is A1: 13 (7.1\%); A2: 169 (92.3\%); A3: $1(0.5 \%)$, with PIC value of 0.12 .

Not Polymorphic For: BglII, EcoRI, HincII, HindIII, KpnI, PstI, SstI, StuI, TaqI and XbaI (5 unrelated individuals tested).

Chromosomal Localization: The CRYA1 gene maps on 21q22.3 (2).

Mendelian Inheritance: Demonstrated in $40 \mathrm{CEPH}$ families.

Probe Availability: Contact C.J.Jaworski.

Acknowledgements: M.B.P. was supported by Danish Research Council and Academy and with a Fulbright Fellowship. S.E.A. was supported by an N.I.H. Grant.

References: 1) Jaworski,C.J. and Piatigorsky,J. (1989) Nature 337, 752 -754. 2) Hawkins,J.W. et al. (1987) Hum. Genet. 76, $375-380$.

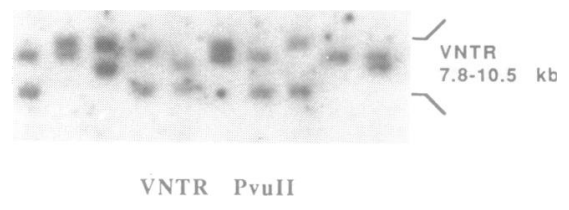

